Article

\title{
How Resilient is Growth? Resilience Assessment of Austrian Municipalities on the Basis of Census Data from 1971 to 2011
}

\author{
Kinga Hat *(1) and Gernot Stöglehner(1) \\ Institute of Spatial Planning, Environmental Planning and Land Rearrangement, University of Natural \\ Resources and Life Sciences Vienna, Peter-Jordan-Strasse 82, 1190 Vienna, Austria; \\ gernot.stoeglehner@boku.ac.at \\ * Correspondence: kinga.hat@boku.ac.at; Tel.: +43-1-476-548-5522
}

Received: 20 February 2019; Accepted: 20 March 2019; Published: 26 March 2019

\begin{abstract}
Living conditions and development perspectives are influenced by territorial inequalities. In this study, an assessment of long-term local and regional resilience was conducted in order to understand the structural strengths and weaknesses in spatial development in Austria. To gain new insights into the known development patterns, a new resilience-oriented assessment was conducted. A growth-oriented assessment was carried out in parallel to provide a reference for interpreting the results. A set of criteria corresponding with each of the two assessment approaches was applied to obtain quantitative results. To determine the spatial dependency of the values' characteristics, spatial statistics was applied. The reinterpretation of existing data and comparison of the results revealed a new level of insight into regional development and made it possible to determine the level of resilience of a region or municipality. The resilience could be evaluated relatively, by comparing the resilience of different spatial units within the study area. Similarities and differences between the results of the two approaches were revealed and discussed. The outcomes confirmed that the growth-oriented perspective is too narrow and further approaches are necessary in order to assess the sustainability and resilience of the local and regional spatial structures and development.
\end{abstract}

Keywords: regional resilience; regional development; resilience assessment; growth assessment; spatial planning; spatial statistics; hot spot analysis; spatial inequality

\section{Introduction}

Growth is considered to be a driving force and a means to achieve prosperity. It is seen as the prerequisite of a high standard of living, thus contributing to the satisfaction of human needs. According to the current state of knowledge, reverting to conventional bases for assessment, the success of a region is based on economic growth [1-4]. Accordingly, economic growth is expected to improve the education system as well as health and safety. Currently, there are no countries that have managed to increase the welfare of their residents without growth [4].

However, already in the second half of the last century, economic growth was contested as the primary goal for development, as was the underlying concept of unlimited growth. These notions were replaced by aiming at a development that creates a balance between ecology and economy [5]. Subsequently, the concept of sustainability was established. It states that ecological, social, and economic goals are equal and that all of them need to be fulfilled for development to be regarded as successful in terms of sustainability [6,7].

In general, sustainability implies the balanced use of existing resources, not exceeding the natural regenerative capacity of a system. A sustainable system should be able to cope with future challenges 
like various crises, disasters, and disturbances that upset or threaten the existence of countries and regions. Without the ability to handle possible crises, a country or region cannot ensure the stability, continuity, and positive development of the living conditions it provides. Being able to bear up to a crisis is generally referred to as resilience. The term resilience describes a quality that is based on the flexibility of a system as well its openness to new solutions, which in turn enable its continued existence when circumstances change unexpectedly [8]. A resilient system has the ability (1) to maintain its own core functions, structures, and identity during a crisis, (2) to restore the disturbed functions and processes after the event, and (3) to adapt to new circumstances and to transform [9-11].

Prosperity, growth, and consumption of resources are not evenly distributed. Different geographical factors and political situations result in different living conditions. Some regions and countries have a high standard of living, while at the same time others cannot even guarantee a minimum standard of living for the population [12]. Based on the existence of resources and infrastructure, as well as the economic performance and employment situation, a distinction is made between structurally strong and structurally weak areas. A stable and continuous provision of goods and services is another determining factor. Structural strength and structural weakness go hand in hand with developmental starting conditions and perspectives that are either above or below average. Behind this background, reducing spatial disparities has been defined as a main goal of (spatial) development in order to provide equal living conditions [13-15].

Therefore, a thorough knowledge of the conditions of the areas under consideration is necessary to effectively manage regional and local development in accordance with this goal. The issue of spatial disparities in regional development and inequalities in living conditions is well represented in national and international scientific and political discourses and, accordingly, various approaches to the subject have been developed. One of the first countrywide assessments on deprivation was developed in England and was based on criteria belonging to material and social deprivation domains [16]. The nationwide comparison of small evaluation areas in England was constantly developed further and is carried out regularly (and correspondingly in Wales, Scotland, and Northern Ireland) [17-20], resulting in a ranking of the most to least disadvantaged units. Meanwhile, the comprehensive evaluation incorporates indicators from seven domains (income, employment, education, health, crime, barriers to housing and services, and living environment). The information serves decision-makers in the process of the distribution of resources and formulation of development strategies [21]. A concept derived from these studies was applied by Heintel et al. (2016) for a regional study in Oberpinzgau in Austria. The potentials and challenges for the region and its municipalities were identified by comparing a peripheral region with an urban agglomeration and was made visible to the political decision-makers [22]. The debate on the spatial disparities is also a dominating discourse in spatial planning in Germany. The supposition that the eastern regions are developing weaker than the western regions of this country and thus offer lower-quality living conditions was verified by means of evaluating labour market regions [23]. A countrywide study on structural strength and weakness, based on the quantitative evaluation of municipalities using indicators like population growth, employment development, female employment rate, employment in primary sector, number of commuters, attractiveness for tourism, and tax revenue, was done in Austria in 2007 [24].

The principal concept of evaluation methods for spatial development normally examines the fulfilment of predefined objectives. They can either be found in planning schemes, strategic, or implementation plans and are viewed as a desired developmental state [25]. In the evaluation process the goals are confronted with corresponding criteria in order to determine to what extent the goals have been achieved in each of the examined entities [26]. Additionally, the examined entities can be compared with each other. Thusly, structurally strong and structurally weak areas can be identified, providing a basis for effectively meeting the needs of less favored areas by means of adequate instruments and measures. Furthermore, the stability of prospering regions can be enhanced $[13,17,18,27]$. 
The indicators used for evaluating success are selected according to the objectives. The mainstream indicators for growth-oriented assessments include the following: Gross domestic product, unemployment rate, employment rate, structure of the economy according to sectors, accessibility and job centrality, provision of infrastructure, patent applications, and balance of trade [4,25]. Incorporating the principles of sustainability into the conceptual framework of the assessment means that not only pure sustainability studies, but all developmental studies and rankings need to be included, which goes beyond direct economic studies to include the ecological and social dimension, in addition to income related living conditions. The additional categories are part of the following subject areas: Health, environmental quality, environmental protection, emissions, drinking water supply, education, security, social commitment and social networking, life satisfaction, supply of services and infrastructure, energy, raw materials and mining, foreign debt, equal rights, poverty, science and technology, social protection system, agriculture and rural development, and urban development $[4,12,21,28,29]$. With regards to equal living conditions, this means that the differences between living conditions on the regional and local level can be made visible if the assessment model is structured accordingly. Due to the complexity of the evaluations, however, the individual indicators' influence on the overall result is difficult to trace.

In order to measure the stability and potential of the continuous improvement of living conditions, regardless of the economic performance and state of a region, the ability of that region to bear up to a crisis must be evaluated. Resilience can either be examined in relation to an individual crisis or it can be viewed as a general concept of strong structures, which withstand multiform crises (such as economic, refugee, energy, food, or climate crises, socio-political challenges, disasters, or impacts of globalization) [30,31].

In this study, an approach for assessing spatial development that focusses on resilience was developed. Austria served as an example to test the approach using data from the recent past. Thus, the long-term structural strength and/or structural weakness of a municipality or region could be recorded over a period of time. The results show a defined degree of resilience. The scope of the degree of resilience allows conclusions to be drawn about spatial disparities. The instrument of resilience-oriented assessment enables new insights into the development patterns of regional development in Austria. A growth-oriented assessment of the structural strength and structural weakness of the Austrian municipalities was carried out in parallel, in order to provide a reference for interpreting the results. The assessments, which were based on two different paradigms, were conducted separately. The comparison of their results made it possible to gain new insights into already known development processes.

The assessment focuses on generic resilience, which is not specifically measured against a defined catastrophe or shock, but rather, is measured in view of unspecified and unpredictable development processes $[30,31]$. The temporal scope was initially designed to cover the last 50 years in order to include the development that followed the reconstruction and stabilization phase after the Second World War. The data were derived from official statistics, allowing a comparable presentation for all municipalities. Checking the data's availability and suitability for a time series analysis resulted in a reduction of the analyzed period to the years 1971-2011, which still allows for the examination of stable economic growth in recent times. In the resilience-oriented assessment concept, the commonly used statistical data were combined in new ways. While constructing the new assessment model, the suitability of the data collected for the assessment of classical growth-oriented development is checked in relation to a new concept, which did not exist at the time the data was gathered. Which of the new indicators are relevant for resilience assessment is also determined.

\section{Materials and Methods}

In the course of the study an assessment model was developed to evaluate regional and local resilience. An assessment based on growth-oriented criteria was used as a reference. Both models are based on the respective theories of regional development and resilience in a certain spatial context. 
The data were processed and executed in GIS. Subsequently, the results were analyzed, interpreted, and discussed (see Figure 1).

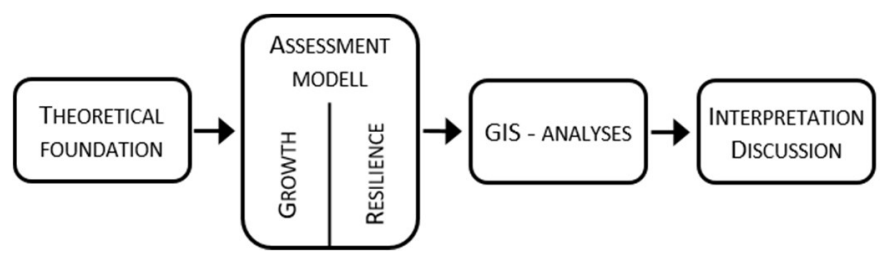

Figure 1. Structure of the study.

\subsection{Spatial Inequalities and Resilience in Theories and Models of Regional Development}

Theoretical explanations concerning the regional distribution of structural strength and weakness are dominated by the topic of economic and regional growth. Neoclassical theories of regional development use simplified models to explain how original interregional differences in the distribution of production factors (labour, capital, and land) are balanced by market mechanisms. Supply and demand lead to factor migrations, whereby interregional differences of factor prices are evened out. If regions stay heterogeneous and specialize, this balance can also be achieved by interregional trade. The critique of neoclassical economics compares the balancing tendencies stated in theory with the persistence of interregional differences that occur in reality and uncover the discrepancies. The original regionally unequal distribution of production factors, as well as natural and institutional barriers, are named as the main reasons for not achieving a balance. In addition, existing inequalities may even be increased by social, political, and economic processes over time [32,33].

As a consequence of this criticism, the theories on polarization in economics and regional development were formulated. The approaches based on polarization theory address diverging sectoral and regional developments. The latter result in the development of dominant and innovative branches of industry that achieve high economies of scale and agglomeration effects and that, according to Perroux (1955), are referred to as motor units (unités motorices). They grow faster than other economic sectors but also have an influence on the other sectors through positive spread effects and negative backwash effects. Boudeville (1966) transferred the sectoral polarization effects to a territorial context. Sectoral polarization creates regional growth poles. Cities forming an industrial agglomeration by accumulating motor units (pôles de développement) represent the core of a growth pole. Positive impulses for growth spread out from such an urban centre onto settlements of lower hierarchical order situated in the outskirts of the city, the sum of which is known as the growth pole (pôle de croissance). The effect of growth poles on the rural periphery (hinterland) can be either advantageous or disadvantageous.

Observance of the possible feedback effects that are brought about by negative and positive events led to the formulation of the hypothesis of circular cumulative causation by Myrdal (1957). In a regional economy, feedback effects can lead to cumulative growth or cause cumulative decline. A distinction is made between the centripetal backwash effects and the centrifugal spread effects. The intensity of these processes determines whether and to what extent spatial disparities will occur. In general, it is not possible to predict which of these development patterns will gain momentum and whether regional development will take a converging or diverging course. According to Myrdal the backwash effects are stronger than the spread effects in the long run. This implication will be all the greater the more pronounced the original differences in development are. Hirschmann (1958) supplements the theory of polarization with the observation that the trickling-down effects gradually outweigh the polarization effects. In the beginning, economic development is dominated by polarization due to agglomeration advantages. Continuous development of the growing region goes hand in hand with increasing agglomeration disadvantages. So eventually, the trickling-down effects will prevail, leading to a reduction of territorial inequalities in the long run. The development gap is closed again [32,34-36].

The centre-periphery models of Prebisch (1959) and Friedmann (1966) tie in with scientific considerations based on polarization theory. These models explain the dynamics of development 
between a rich and industrially developed centre and an underdeveloped exploited periphery. The asymmetric relationship is based on an unequal trade-off, as follows: The centre grows and develops at the expense of the periphery. These approaches assume that innovation leads to sectoral and territorial imbalances. As a result, the centres wield power and influence over the dependent periphery, causing processes that contribute to the further growth of the centre. The centre and the periphery form a closed system, the relationship between these two territorial entities is characterized by authority and dependence $[32,33,37]$.

The neoclassical approaches and models based on polarization theory partly contradict empirical experience on the global distribution of wealth. Therefore, other theoretical approaches have tried to model and explain processes of economic development. According to demand-oriented approaches, the causes of growth can be traced back to influences coming from outside the region (export base theory) or to activities emanating from the region itself (endogenous growth theory). Another model is represented by the new economic geography approach according to Krugman. The causes of the agglomeration of economic activity are divided into "first nature" agglomerations, which depend on resources and climate conditions, and "second nature" agglomerations, which are based on endogenous circular processes. Important factors influencing these secondary agglomeration processes are mainly the economies of scale within an economic sector, low transport costs, and the independence of industry from the discovery sites of natural resources. This leads to the creation of dense markets (labour market pooling), market size effects, and positive spill-over effects [34].

These approaches describe spatial development patterns in the light of (economic) growth. From an economic growth-orientated viewpoint, resilience is defined as the ability to return to the growth rates of the gross domestic product, as well as to the employment rates that prevailed before the crisis, as quickly as possible $[38,39]$. An alternative approach based on environmental science focuses on the spatial structures that enable basic needs to be met. The spatially relevant basic functions of existence are the following: Housing, working, provision of goods and services and disposal, education, recreation, mobility, communication, and taking part in social life [40]. The activities necessary for fulfilling these needs are considered the basic functions of a regional system. They represent the basis for the activities of each person and the entire region and they require appropriate spatial structures and resources. What are the characteristics spatial structures and society needs to feature in order to make it possible to maintain the basic functions in the face of a crisis or critical change? Keeping up the basic functions will enable restoring the disturbed processes after a crisis, adapting to the new conditions, and, if necessary, transforming in accordance with the new situation.

To find an answer to this question, this study resorts to the concept of spatial resilience by Stoeglehner et al. (2016). According to this concept, spatial resilience consists of physical and social strength. Physical strength can be explained by four principles, as follows: Efficiency, exposure, diversity, and redundancy. The explanation of these principles also deals with how they apply to a spatial context. Efficiency means the optimized relationship between performance and result. It stands for making use of existing forces and using resources wisely. Efficient spatial structures enable short supply routes, an efficient use of infrastructure through moderate density, proximity, and compactness. Diversity requires a mix of structures and functions. The fact that functions are fulfilled in manifold ways means that the system will feature different sensitivities relating to disturbances. It also means that the foundation of the system has heterogeneous components that it can revert to alternately in case of a shock.

The most important implication for spatial development is a mix of functions through the physical proximity of places of residence and working. The social mix provides the basis for good social capital. Exposure expresses to what extent a system is exposed to danger or crisis. So as not to be unduly exposed, dependency from external forces needs to be minimized and the level of self-sufficiency within the system should be high. Therefore, short distances are important for carrying out daily activities and providing goods and services. Using the resources available in the region lessens exposure. Redundancy means that components exist in the system that are the same or similar. In 
a crisis, the additional elements ensure the continuity of functions. Due to the use of additional structures and the multiple uses of existing forces and structures, the functions can continue to be performed by supplementary elements (basic functions of existence) if part of the resources should drop out or become unavailable altogether. These principles do not compete against each other, but rather complement each other. It is not possible to strictly allocate parts of the system design to the individual principles in the light of the social and economic resilience. The principles complement each other, yet they cannot replace each other. The establishment of one principle can go only as far as no other criterion is excluded $[9,41,42]$.

The principles related to the social aspects have two components, social strength and the ability to learn. Social strength is seen as a prerequisite for strengthening the stability and resistance of the system. It is based on social cohesion and society's ability to communicate and cooperate. In this context, social capital is described by the following three main characteristics: Bonding-cohesion within social groups, bridging-cohesion and cooperation between different groups, and linking-functioning hierarchical relationships and faith in authorities and institutions [43]. The ability to learn is a prerequisite for the remaining principles. Since resilience is a process and not a stable state, in society, a willingness to change and innovation are necessary to enable the processes of adaptation and transformation in the event of a crisis or to enable foresighted preparations for foreseeable events and changes. The principles of social strength and ability to learn enclose similar aspects as the concept of social vulnerability. A vulnerable society lacks the capability of self-organization and is more exposed to possible disruption or disturbance. For instance, when facing a disaster induced by natural occurrences, the ability to anticipate, cope with, resist, and effectively recover is crucial to minimize losses and resume the functionality of the disrupted system [44].

\subsection{Concept for the Assessment}

This study evaluates structural strength and weakness, on the local and regional level, over a long period of time in Austria. The assessment is carried out for the whole country at the aggregation level of individual municipalities over the time period of the last 40 years. Two different objectives, which are ascribed to two different development perspectives, are defined for the examined spatial development processes, namely growth and resilience. To determine how these objectives are met, corresponding indicators are selected and quantitative assessments are conducted. A set of ten indicators is presented for measuring the fulfilment of the above-mentioned principles of resilience. The second set consists of six indicators and is used to measure economic and demographic growth. For each year under survey, one assessment follows the resilience-oriented perspective and the other one follows the growth-oriented perspective. Finally, the results are compared and analyzed.

\subsubsection{Data Basis}

The time series of the 1971, 1981, 1991, and 2001 censuses and the 2011 register census are the data basis for the analyses. The data are obtained from the statistical database of Statistics Austria (STATcube). The following properties are considered: Demographic characteristics, employment status, level of education, occupational characteristics, and commuter characteristics of the population by municipality of the place of residence or the place of work or school. Those indicators that could be calculated on the basis of data from this time period at the municipal level in the planned time series are taken into account. Data with lower spatial accuracies are excluded so as not to flatten the results. Based on the selected data, the calculations are carried out on the status of the administrative municipal boundaries as of 1 January 2011, which resulted in a sample size of 2379 administrative units, on the municipal scale, covering the whole country.

\subsubsection{Selection of Indicators}

The indicators are selected by means of a literature research on selected regional development studies, development rankings, and analyses. The literature survey focused on studies evaluating 
regional resilience. Thus, the tested resilience-oriented bases of evaluation were conflated. Further studies on regional development and deprivation form the basis for compiling the growth-oriented indicators. These studies are also an additional source for integrating demographic and economic data into the criteria indicating resilience.

For the resilience-oriented assessment, indicators that are able to reflect the defined design principles are recorded. The principles of resilience, substantiated by sub-goals derived from these principles, are declared as the goals to be achieved, meaning the desired state in spatial development. Those indicators that are calculable by means of the project's data basis and that give quantitative evidence of the degree to which the desired state has been achieved are selected. A subset of these indicators is compiled covering most of the sub-goals and avoiding redundancies at the same time. The calculation model includes indicators that are proven most significant in literature and existing studies and that are available for all Austrian municipalities in the examined time period. Some indicators signify more than one dimension of resilience. There are also overlaps and, depending on the interpretation, the individual indicators can be assigned to different aspects of resilience. In the calculation model, each indicator is included only once, even if it could be allocated to several different aspects. The interpretation and allocation are explained in the following paragraphs and in Table 1.

Table 1. Principles of resilience and selection of indicators.

\begin{tabular}{|c|c|c|}
\hline Principles of Resilience & Indicator & $\begin{array}{l}\text { Basis of Calculation (W) Municipality of Place of Work, (R) } \\
\text { Municipality of Place of Residence }\end{array}$ \\
\hline Ability to learn & $\begin{array}{l}\text { Innovation potential, willingness to } \\
\text { change }\end{array}$ & $\begin{array}{l}\text { Percentage of the population with higher education (the larger } \\
\text { the percentage, the higher the rating) }\end{array}$ \\
\hline \multirow{2}{*}{ Social strength } & Migration balance & $\begin{array}{l}\text { Migration balance per inhabitant (whole of Austria as } \\
\text { reference) }\end{array}$ \\
\hline & Willingness to do voluntary work & $\begin{array}{l}\text { Percentage of the population with higher education (the larger } \\
\text { the percentage, the higher the rating) }\end{array}$ \\
\hline \multirow{2}{*}{ Efficiency } & $\begin{array}{l}\text { Proximity of places of residence and } \\
\text { work, principle of short distances, } \\
\text { mixed uses }\end{array}$ & $\begin{array}{l}\text { Internal work commuters/employed persons }(\mathrm{R}) \text { and internal } \\
\text { work commuters/employed persons }(\mathrm{W}) \text { (the greater the } \\
\text { proportion of internal commuters, the higher the rating) }\end{array}$ \\
\hline & Employment rate (use of existing forces) & $\begin{array}{l}\text { Employed persons }(\mathrm{R}) / \text { total population at working age (ages } \\
\text { 15-64) (the higher the share of employed persons the higher } \\
\text { the rating) }\end{array}$ \\
\hline \multirow{3}{*}{ Exposition } & $\begin{array}{l}\text { Proximity of places of residence and } \\
\text { work, principle of short distances, } \\
\text { mixed uses }\end{array}$ & $\begin{array}{l}\text { Internal work commuters/employed persons }(\mathrm{R}) \text { and internal } \\
\text { work commuters/employed persons }(\mathrm{W}) \text { (the greater the } \\
\text { proportion of internal commuters, the higher the rating) }\end{array}$ \\
\hline & Available school places & $\begin{array}{l}\text { School internal commuters (R)/pupils and students (R) and } \\
\text { internal school commuters (R)/pupils and students (W) }\end{array}$ \\
\hline & $\begin{array}{l}\text { Distribution of unemployed persons } \\
\text { among the age groups }\end{array}$ & $\begin{array}{l}\text { Distribution of unemployed persons in the following age } \\
\text { groups: ages 15-29, 30-49, 50-64 (whole of Austria as a } \\
\text { reference) }\end{array}$ \\
\hline \multirow{3}{*}{ Diversity } & Balanced age structure of the population & $\begin{array}{l}\text { Distribution of the population in the following age groups: } \\
\text { under } 15,15-29,30-49,50-64,65+\text { (whole of Austria as } \\
\text { reference) }\end{array}$ \\
\hline & Potential work force women / men & $\begin{array}{l}\text { Number of women/number of men of working age (ages } \\
\text { 15-64) (R) (whole of Austria as reference) }\end{array}$ \\
\hline & Differentiation of the economy & $\begin{array}{l}\text { Distribution of employees by economic sector (W) (total } \\
\text { Austria as reference) }\end{array}$ \\
\hline \multirow{3}{*}{ Redundancy } & $\begin{array}{l}\text { Participation of women and men in the } \\
\text { labour market }\end{array}$ & $\begin{array}{l}\text { Difference between the labour force participation rate of } \\
\text { women and the labour force participation rate of men (whole } \\
\text { of Austria as reference) }\end{array}$ \\
\hline & $\begin{array}{l}\text { Employment rate (better distribution of } \\
\text { resources among the population) }\end{array}$ & $\begin{array}{l}\text { Employed persons }(\mathrm{R}) / \text { total population of working age (ages } \\
\text { 15-64) (the higher the share of the employed the higher the } \\
\text { rating) }\end{array}$ \\
\hline & Potential work force women/men & $\begin{array}{l}\text { Number of women/number of men of working age (ages } \\
\text { 15-64) (R) (whole of Austria as reference) }\end{array}$ \\
\hline
\end{tabular}

Innovation potential and willingness to change are measured by the percentage of the population with higher education. The ability to learn builds on knowledge and experience from the past as well as on forward looking planning of future developments. Higher education stands for access 
to knowledge (from a societal, not an infrastructure-related perspective). A higher percentage of educated people is assumed as a starting point for society's ability to anticipate future developments. In case of a changed situation or changed circumstances a higher level of education and knowledge may cause necessary solutions to be developed faster or even pro-actively. An analysis of the current situation and the anticipation of possible difficulties can lead to forward-looking management and thus lessen the impact of potential negative effects of a crisis. In general, crisis or not, a high qualification increases innovativeness [38]. In addition, this indicator also stands for social strength, since people with a higher level of education are clearly more often involved in volunteering than others [45]. The willingness to volunteer is one of the expressions of social strength (bridging and bonding) [46]. Furthermore, the social strength of a community is reflected in the migration balance. A high level of out-migration signals massive problems in managing everyday life in the community and insufficient opportunities to earn a living. It also points to a lower attractiveness of the municipality as the centre of one's life [31,46]. A negative migration balance reveals that the binding effect of social strength is insufficient, the society is not networked and shows higher social vulnerability [44].

Excessive in-migration is viewed as "bubble development", which leads to uncertainties, weakens the balance of the system, and thus impairs resilience [38]. For evaluating the migration balance, the Austrian average value for the respective valuation year is used as a reference. The result of the study enables a comparison between the municipalities and illustrates the change in the distribution of structural strength and structural weakness over time. Using an external and hypothetically ideal value would not have increased the result's relevance concerning resilience since there is no agreed upon unconditional resilience state for this matter. Additionally, making comparisons within the investigated area and the highlighting of spatial disparities would have been more difficult $[18,26,47]$. With the Austrian average, it is possible to set a realistic target value for the migration balance corresponding to the national conditions. This valuation approach was also used for other selected indicators.

The mix of uses, which is related to the proximity of places of residence and work and enables short distances for commuting and supply, stands for efficiency. If there is spatial proximity and opportunities to manage everyday life within the community are sufficient, the available labour force is used within the community and the resource costs for daily routes are kept low. At the same time, a community which is less dependent on commuter flows (outbound and incoming commuters) will have a higher degree of self-sufficiency, which is equivalent to lower exposure. These principles were also used to assess the amount of available school places. The more people find a school or training place within the municipality they live in, the shorter the average commuting distances are and the lower the external dependency is, which reduces exposure. For each of the two indicators, the percentage of internal work or training commuters of the employed persons or persons in training by place of residence is calculated, as is the percentage of work places/training places covered by the local population (see Table 1). This approach is used to measure the availability and suitability of jobs and training places for the local population. In our model, the assessment of efficiency supplements the employment rate. The employment rate is an indicator which is also used in growth-oriented assessments of economic viability, but it also stands for the use of available resources and can therefore serve as a basis for assessing efficiency [47]. In addition to the indicators already mentioned, the distribution of unemployed persons among the age groups is used to assess exposure. This enhanced approach for recording the situation on the labour market examines whether access to the labour market is evenly distributed without discriminating an age group or exposing it to additional difficulties. The approach also checks whether the available human resources are used sustainably.

Diversity is assessed by means of the sectoral economic structure. The diversification of the economy creates a basic condition that helps to lessen dependency on individual sectors and that builds on elements with different vulnerabilities to various crises. Most studies on the evaluation of development and wealth assess the importance of the selected economic sectors. The high degree of development is often equated with the expansion of the tertiary sector [4]. In the event of a crisis, a high proportion of export-oriented industrial production can lead to major disruptions and difficulties in 
maintaining regional functions [39]. A dominant primary sector may not be able to provide sufficient livelihoods if a climate crisis or catastrophe induced by natural processes occurs. A diversified economy should be based on all three sectors in order to keep vulnerability to crises low [48]. In order to determine the contribution of each economic sector, how the workforce is distributed among the three sectors is assessed. Since it is not possible to name an optimal distribution of the workforce among the economic sectors, the model used the national values as target values at each point of valuation. This in turn made it possible to compare the valuation units in the study area with each other by clearly highlighting the differences.

The age structure of the population provides a basis for assessing the differentiation and diversity of goods and services offered in an area. The population is divided into five age groups (under 15, 15-29, $30-49,50-64$, and 65+). How the percentage of people in these age groups compares to the respective national average values that are used as a target values is assessed. This way the heterogeneity of society and the variety of potential contributions of the different groups can be illustrated. In addition, the evaluation of the functionality of the entire system is included in the assessment model by means of the balanced presence of all age groups. Together the balanced presence of women and men in society and the balanced presence of the age structure both signify diversity of local and regional living conditions and job opportunities. Such balanced conditions would allow people of all age groups and of both sexes to establish their centre of life in a community. When the quality of location is particularly poor, the people who are the most mobile begin to leave the community. Most often these are the young women. They move to the cities where they have better prospects on the labour market, better training opportunities, and broader perspectives for building up and organizing their private lives. This creates an asymmetry where the quality of location is particularly low in some areas and particularly high in others [49]. In the model, the values are determined on the basis of the ratio of the number of women and men of working age and evaluated according to their difference to the national average. The employment potential of women and men also indicates redundancy. In a strong, well-functioning regional society, this ratio is usually balanced. There are various reasons for an increased out-migration of young women but, in addition to personal motives, this tendency points to poor infrastructure at the local and regional levels. The lack of infrastructure limits the possibilities of coping with everyday life in a satisfactory way, which in turn leads to a reduction of the potential forces because of the out-migration of young women [50]. If not many women return at a later time, this will lead to a general gender imbalance in the community and a part of the potential forces will be missing. The predominance of women in the population also points to an unbalanced structure of society and is regarded negative in the assessment model.

Aside from the potential workforce of women and men, two further indicators are used as a basis for assessing redundancy, one of them being the participation of women and men in the labour market. By using this indicator redundancy of the fundament of system upkeep is included in the model, starting from the smallest unit of the system, meaning a household or family. If the support of a family is based on two pillars, the support can be kept up even in the event of a labour market crisis or if the need for unpaid employment arises and one of the incomes is lost, because there is still a second financial basis [49]. Together with the assessment of the employment rate, this indicator points to the distribution of resources among the population [47,51].

The second set is a compilation of indicators reflecting growth (see Table 2). The attractiveness of the municipalities as the centre of life is measured by the population development in the time span between two census dates [24]. The labour market situation is represented by the employment rate and unemployment rate. The more people find employment, the greater is the economic attractiveness of the municipality [23]. A low unemployment rate indicates good economic opportunities and good prospects for the local population [52]. The attractiveness of a municipality for tourism implies interesting natural, cultural, or historical potentials of the region. Together with tourism infrastructure, these potentials represent an ideal basis for tourism development. The development status of the economy in general is determined by the importance of the service sector [4,23]. Accessibility, which 
indicates location quality and dependence on other centres, is evaluated on the basis of the proportion of people who have long commuting distances to work [25].

Table 2. Growth oriented characteristics.

\begin{tabular}{|c|c|c|}
\hline Evidence of Structural Strength & Indicator & $\begin{array}{l}\text { Calculation (W) Municipality of Place of Work, } \\
\text { (R) Municipality of Place of Residence }\end{array}$ \\
\hline $\begin{array}{l}\text { Attractiveness of a municipality as } \\
\text { centre of life }\end{array}$ & Population development in \% & $\begin{array}{l}\text { Total population }(\mathrm{R}) \text { at census date/total } \\
\text { population }(\mathrm{R}) \text { at previous census date }\end{array}$ \\
\hline Labour market situation & Employment rate & $\begin{array}{l}\text { Employed persons }(\mathrm{R}) / \text { total population at working } \\
\qquad \text { age }^{*} 100(\mathrm{R})\end{array}$ \\
\hline $\begin{array}{l}\text { Economic opportunities and } \\
\text { perspectives for the local } \\
\text { population }\end{array}$ & Unemployment rate & $\begin{array}{l}\text { Unemployed persons }(\mathrm{R}) / \text { labour force (employed } \\
\text { persons + registered unemployed persons) }(\mathrm{R}) * 100\end{array}$ \\
\hline $\begin{array}{l}\text { Attractiveness of the municipality } \\
\text { for tourism }\end{array}$ & $\begin{array}{c}\text { Persons employed in the accommodation and } \\
\text { hospitality sector }\end{array}$ & $\begin{array}{l}\text { Persons employed in the accommodation and } \\
\text { hospitality sector }(W) / \text { employed persons }(W)\end{array}$ \\
\hline $\begin{array}{l}\text { High developmental level of the } \\
\text { economy }\end{array}$ & $\begin{array}{c}\text { Proportion of persons employed in the } \\
\text { service sector }\end{array}$ & $\begin{array}{l}\text { Employed persons in the service sector } \\
\text { (W)/employed persons (W) }\end{array}$ \\
\hline $\begin{array}{l}\text { Accessibility, dependence on } \\
\text { (other) centres }\end{array}$ & $\begin{array}{l}\text { Proportion of daily commuters with } \\
\text { commuting distances }>60 \text { min and non-daily } \\
\text { commuters to employed persons }\end{array}$ & $\begin{array}{c}\text { Commuting distance }>60 \text { Min }+ \text { non-daily } \\
\text { commuters (employed commuters /employed } \\
\text { persons in the municipality) }(\mathrm{R})\end{array}$ \\
\hline
\end{tabular}

\subsubsection{GIS-Model and Calculations}

The evaluation procedure follows the procedure of a utility analysis. The selected evaluation criteria reflect the achievement of the regional development objectives, which are defined previously. The first step is to calculate the values of the individual indicators for each municipality. In order to make the indicators' different value distributions in the separate municipalities comparable, the indicators are standardized. On the basis of the values of the respective criterion, dimensionless target fulfilment values are calculated for each indicator. For this purpose, a range between 0 and 100 is defined. The value of a criterion that fulfils the objective the most is set to 100 and 0 is assigned to the value that represents the lowest achievement of the objective. For each indicator, which trend of the values is in alignment with achieving the target is defined. This means that either (A) the highest (e.g., proportion of persons with higher education) or (B) the lowest (e.g., unemployment) values are in alignment with achieving the target. The calculation formula for standardizing the indicators is adjusted according to this distribution. The value range is defined for each indicator by using the following basic formula, according to the target value definition:

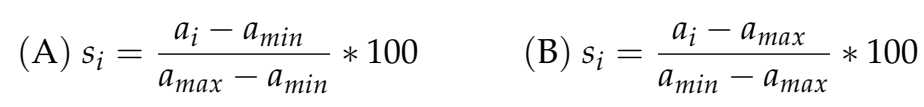

where $s_{i}$-the standardized value of the indicator in a municipality; $a_{i}$ - the value of the indicator in a municipality; and $a_{\min }$ and $a_{\max }$ - the minimum and maximum value of the indicator.

For those indicators, for which the Austrian average is set as the target value (e.g., differentiation of the economy), first the differences to the average are calculated before the standardization formula is applied.

The final results are determined by two different methods. The first method determines the structural strength and weakness by calculating the arithmetic mean of the equally weighted standardized indicator values at each point in time (1971, 1981, 1991, 2001, and 2011) for each municipality. The table of results is then linked to the municipal boundaries.

The second method is based on spatial statistics. Hot spot analysis (Getis-Ord Gi* statistics) is used to identify the statistically significant spatial clusters of the high and low values of the respective indicator. Based on the spatial dependence of the values, the procedure determines the statistical significance of the spatial clusters of high values (hot spots) and low values (cold spots). The calculation is based on spatial correlation and includes the statistics of distances between the elements [53]. This analysis is performed using ESRI's ArcGIS 10.5.1 software. The probability ( $p$-values) and standard 
deviation (Z-values) are calculated. The $p$-values determine to what extent the particular spatial pattern is generated by a random process. The lower the $p$-value, the lower the probability that the pattern is the result of random processes. The Z-values and the $p$-values are interrelated to the standard normal distribution. Very high or very low $Z$-values together with very low $p$-values imply a very low probability that the observed spatial patterns are distributed randomly. So the confidence level of statistical significance becomes apparent and subsequently clusters of positive values are classified as hot spots and clusters of negative values as cold spots [54,55]. The criteria and values for the determined classes can be found in Table 3. Finally, the final result is determined for each area by summing up the results of this classification according to the principle of equal weighting of indicators.

Table 3. Critical $p$-values and Z-values for the different confidence levels and assigned classes of statistical significance. All other value combinations that do not include statistically significant features were assigned a value of 0 .

\begin{tabular}{ccccc}
\hline $\begin{array}{c}\text { Z-Value } \\
\text { (Standard Deviation) }\end{array}$ & $\begin{array}{c}p \text {-Value } \\
\text { (Probability) }\end{array}$ & Confidence Level & Hot-Spot Class & Cold-Spot Class \\
\hline$<-1.65$ or $>+1.65$ & $<0.10$ & $90 \%$ & 1 & -1 \\
\hline$<-1.96$ or $>+1.96$ & $<0.05$ & $95 \%$ & 2 & -2 \\
\hline$<-2.58$ or $>+2.58$ & $<0.01$ & $99 \%$ & 3 & -3 \\
\hline
\end{tabular}

\subsection{Interpretation Method}

The interpretation is based on a verbal-argumentative content analysis. First, the result maps are examined in the time series according to the respective assessment method. Then, the results of the growth-oriented and resilience-oriented assessments are processed in a comparative analysis of the regions and the differences and similarities are interpreted in a hermeneutic process.

\section{Results and Discussion}

\subsection{Comparison of Calculation Methods}

The results are gained by two different methodological procedures. The difference in how structural strength and structural weakness are determined in these procedures is whether or not spatial statistics is included for identifying the spatial significance of indicator values. Figure 2 shows examples of the results of the two assessment methods. The comparison of these results (of one assessment year and of the same objective for spatial development) shows to what extent applying spatial statistics conceals the calculated values at the local level. Identifying the exact results of the individual municipalities and, in particular, of the regionally atypical values is only possible in the calculation without spatial statistics. However, the generalization allows a quick and clear overview of the most important spatial clusters of low and high values. Local and regional development always occurs in correlation with adjacent areas. A cluster representation makes regional differentiation easier, which is why the results based on the hot spot analysis form a better basis for the upcoming qualitative regional analysis and are therefore used in the following representation of the results. The results of the calculation that are not based on spatial statistics make it possible to identify independent values for each municipality and therefore they are used as additional information for the interpretation of the results. 


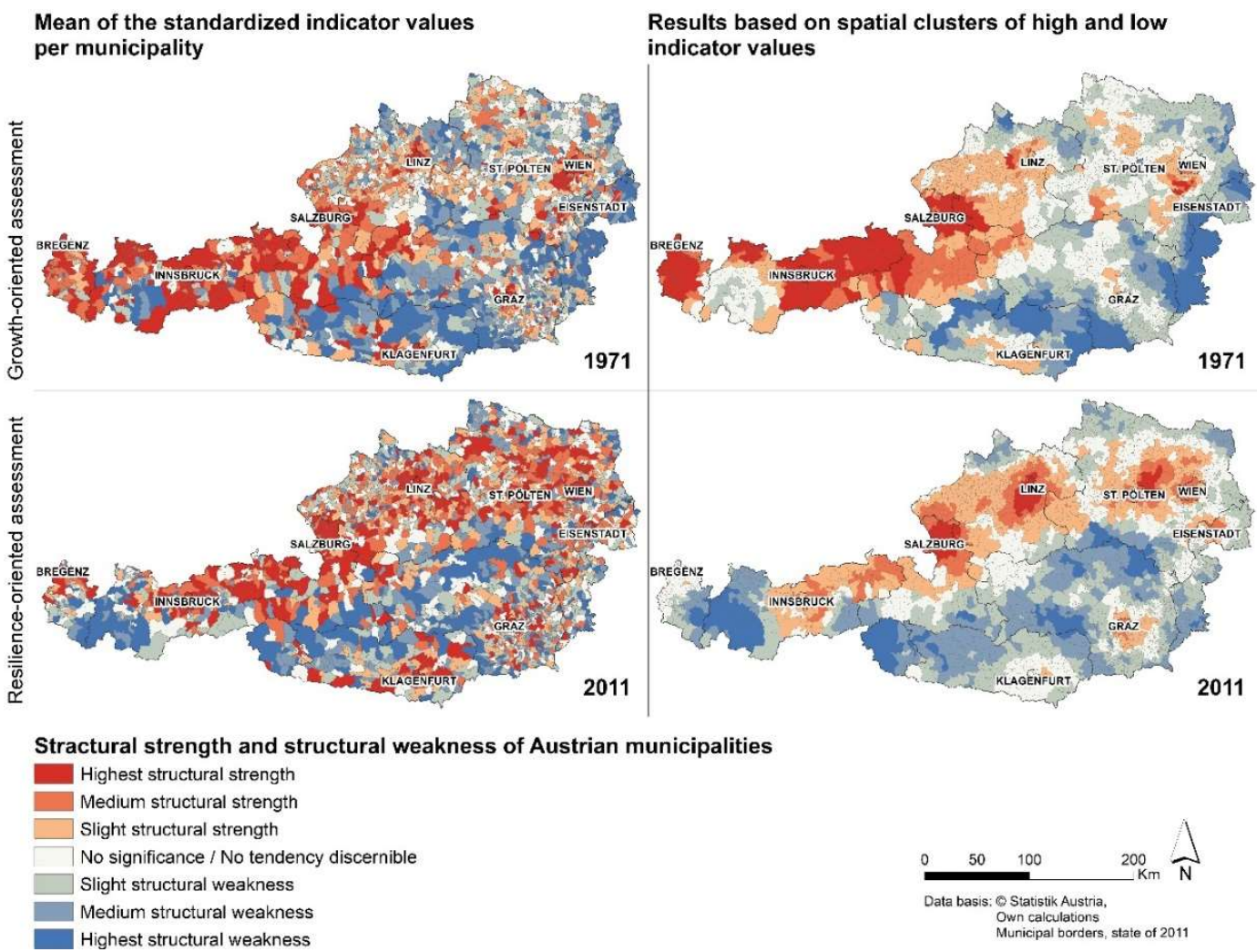

Figure 2. Comparison of the assessment methods. Arithmetic average per municipality (above) and sum of the results of the hot spot analysis of the separate indicators (below).

\subsection{Structural Strength and Structural Weakness in Austria's Spatial Development}

The maps in Figure 3 show the time series of the growth-oriented and the resilience-oriented assessments of structural strength and structural weakness. The evaluation of how structural strength and structural weakness are distributed presents both similarities as well as clear differences. When the growth-oriented criteria were applied, the distribution of structural strength and structural weakness mostly remained stable over time. When the resilience-oriented criteria were used for the evaluation, a significantly greater variation in regional results was observed in the time series. 
Structural strength and structural weakness of Austrian municipalities

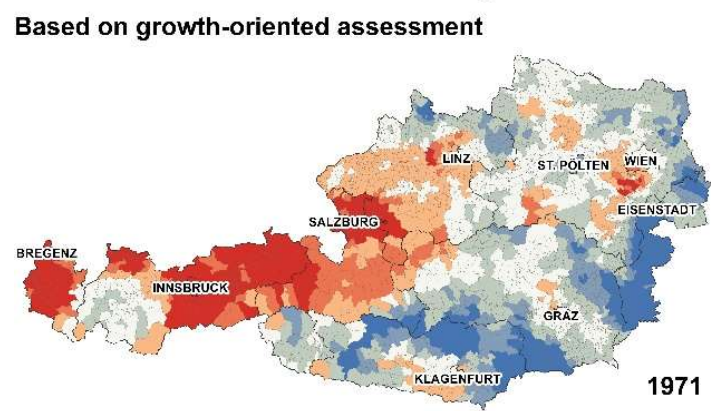

Based on resilience-oriented assessment
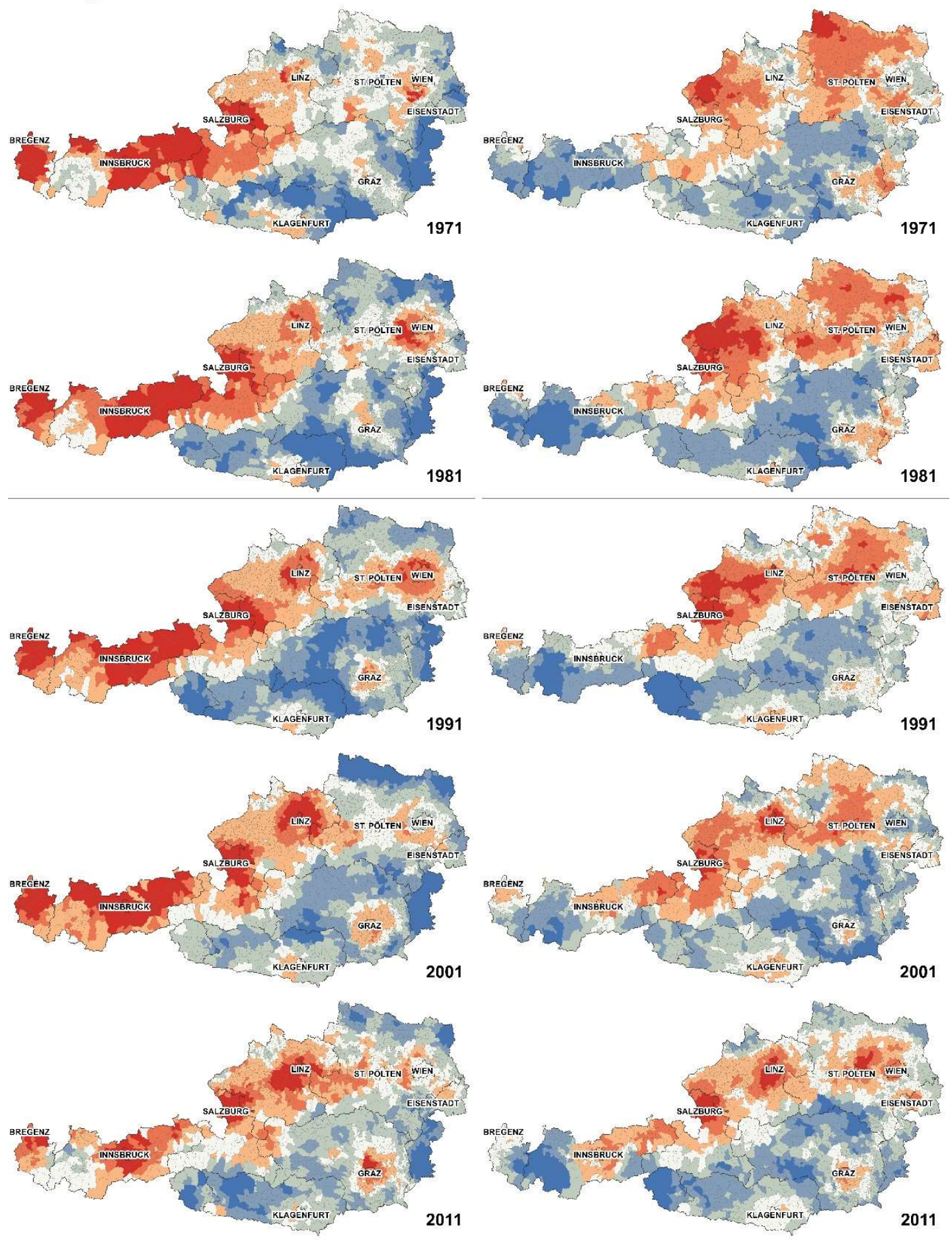

Summarized spatial significance of indicator values
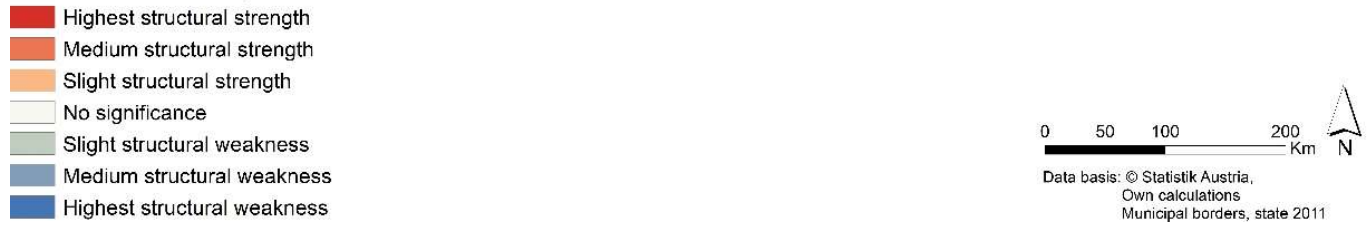

Figure 3. Comparison of the evaluation results of the municipalities according to a growth-oriented perspective and resilience principles. Method: Analysis of the spatial clusters of the high and low indicator values (hot spot analysis). 
In the growth-oriented assessment there is a distinct and strong east-west axis. It goes from Vienna via St. Pölten, Linz, Wels, Salzburg, and the Inntal valley to the Rhine valley at the western state border. The structurally strong regions along this axis include the agglomerations with their respective adjacent areas, such as the central regions of Upper Austria and Salzburg as well as the valleys of the Inn and Rhine. Away from the east-west axis, however, with less pronounced structural strength, there are further central regions, the central region of Graz and, only slightly discernible, the central regions of Carinthia and Eisenstadt. According to the growth-oriented perspective the regions within the inner Alpine areas are considered to be structurally weak, including Styria, except for Graz and its surroundings, East Tyrol, and Carinthia with adjacent parts of Salzburg (Lungau) and the parts of Lower Austria alongside the border to Styria. Other structurally weak regions are located in the regions alongside the border to the countries of the former Eastern Bloc, including Burgenland, Weinviertel, and Waldviertel in Lower Austria. This classification considerably coincides with the usual results of common studies on structural strength and weakness concerning the whole of Austria, as well as sub-themes, such as the declining of population and the shrinking, migration, and ageing of society, unequal development of rural and urban areas as well as periphery and centres, commuter relations, economic performance and growth, as well as the job situation $[2,12,24,56,57]$. The consistency of the growth-oriented assessment's results with conventional studies on spatial development, demography, and economy supports the selected combination of indicators. In addition, the polarization effects along the east-west axis in the regions of Linz, Salzburg, Innsbruck, and Bregenz become apparent over time. As can be seen on the results maps, these cities have developed positively in terms of growth by means of cumulative withdrawal processes at the expense of their surrounding areas. In contrast, the development in Graz took a different course. Over the period under study this city gained in structural strength. Here, both processes can be observed, as follows: Cumulative decline, which manifests as permanent structural weakness and occurs in the areas further away from Graz, as well as cumulative growth, whereby the agglomeration effects and the strong role the city plays in the region spreads out to the directly surrounding area, in accordance with Myrdal (1957) [36], Hirschmann (1959) [35], and Friedmann (1966) [58].

In the resilience-oriented assessment, the distribution of structural strength and structural weakness, in the beginning of the period under study, differs considerably from the results in the growth-oriented assessment. The resilience-based structural strength is apparent in Salzburg, in the west of Upper Austria, and adjacent parts of the northern Obersteiermark region of Styria. With the exception of the areas east of Vienna and in southern Lower Austria, Lower Austria also belongs to the structurally strong regions and at the time of the first analysis (1971). The Waldviertel region had the highest concentration of positively evaluated areas in that province. Another structurally strong region was situated in southern Burgenland and in the adjacent parts of Styria. This distribution changed over the period under study. It must be noted that a structurally strong centre developed in Linz. On the one hand, the resilient structural strength in Upper Austria and Salzburg concentrated around the cities more and more, which indicates that the cumulative decline was outweighed by the backwash of production factors and development potentials from the surrounding regions. On the other hand, resilient structural strength increased over a longer time period in the areas southwest of Salzburg due to the balancing trickling-down effects of the well-positioned agglomeration (in accordance with: Myrdal 1957, Hirschmann 1959). A further development, which resembles the process of the formation of a growth pole according to Perroux, occurred in the region of Innsbruck. At first this area was evaluated as not resilient. Gradually, the emergence of a slightly resilient area that has its core in Innsbruck can be observed. If this economic growth theory is applied to the growth of resilience in the region, then the areas where the principles of resilience are fulfilled can be interpreted as motor units, which stimulate positive impulses for a balanced development and which, in turn, spread out further to the surrounding area.

The results in Lower Austria moved in the opposite direction. In the period up to 2001, the level of resilience was high in the Waldviertel and Weinviertel regions. A gradual downward spiral 
began in 1991 until these areas revealed a low degree of resilience at the end of the analyzed period (2011). The evaluation shows that, in Lower Austria, only the central area around St. Pölten and the western outskirts of Vienna have a high level of resilience at the end of the analyzed period. In southern Burgenland there was relative resilience in the analyzed period of 1971-1981, which declined sharply from 1991 onwards. In Vorarlberg the situation is different again. There, the Rheintal (Rhine valley) region shows a slight resilience throughout the observation period. The remaining parts of Austria either showed no particular tendency or were assessed as structurally not resilient. The inner Alpine areas in Styria, East Tyrol, Carinthia, and the Tyrolean Oberland were and stayed non-resilient throughout the entire analyzed period, with only minor changes. Vienna showed a structural weakness for many years (until 2001) until the capital developed a resilient structural strength in 2011. The fact that the dynamic in the distribution of resilient and non-resilient regions during the observation period is generally high compared to the distribution of conventionally defined structural strength and structural weakness corresponds to the definition of resilience. Since resilience represents an ability to survive crises and to adapt anew, rather than describing a permanent state, it can be assumed that, even though resilient structures are currently concentrated around the large centres, future developments might result in a different distribution of resilience $[8,11,47]$.

The comparison of the growth-oriented and resilience-oriented results leads to the answer of this study's initial question. Depending on the area, there are different answers to how growth and resilience might be combined in regional development. In some regions, economic growth and resilience continuously go hand in hand for years. In particular, the positive results of the two evaluations that were based on two different objectives were similar in Upper Austria and Salzburg. This is an indicator of balanced structures which, in turn, enable a balanced development of society. In these areas there were no spatial clusters of individual resilience indicators with low values, especially at the more recent analysis dates (2001 and 2011). In Salzburg and Upper Austria, the ratio of the service sector was always relatively lower in favor of the other two economic sectors over the entire analyzed period, which brings about more diverse economic development perspectives. Due to the differentiation of the economy and the broad range of offers, there is a professional and private livelihood for people of all age groups, of both sexes, and in different stages of life. A correspondingly high employment rate and the participation of women in the labour market are signs of lower exposure and the fact that there is a buffer. This region is able to prosper economically and be better prepared to withstand potential crises at the same time.

It must be noted that likewise, in both assessments the surroundings of agglomerations showed a tendency to increase the concentration of structural strength. What dimension this polarization effect had depended on the city, but it almost always occurred. The process of increasingly pronounced polarization when structural strength concentrates in large cities supports the theories of regional development. At the same time, this process is connected to the changes in how people organize their lives over the years. A shift of economic activity from rural areas to agglomerations is part of the global trend, where an increasing share of the world's domestic product is produced in urban areas and the share of the urban population is increasing rapidly [59]. Planning one's life and coping with everyday life is easier in urban agglomerations than in peripheral areas. Better access to the labour market, shorter distances, and no drawbacks resulting from (selective) out-migration have a positive effect on social life and on the maintenance and development of infrastructure [48].

Yet, there are regions with a weaker resilience despite their high economic performance. Tyrol and Vorarlberg feature this antagonism on a permanent basis. In the growth-oriented assessment, the north of Tyrol and Vorarlberg stood out due to their very marked structural strength. However, large parts of these provinces, in particular the west of Tyrol as well as Vorarlberg (with the exception of the region of Bregenz), are very weak in the resilience-oriented assessment. The economic strength in these areas is one-sidedly based on tourism. Intensive economic development, especially of winter tourism [60], is mainly an answer to the demand from outside the region. Due to the attractiveness of the region, infrastructure was built and further developed and so the local assets were turned into 
export goods, which external consumers were able to purchase. The one-sided development of the economy focuses mainly on this export-oriented sector. Demand from within the region remains low, employment opportunities are mainly limited to tourism and related economic branches, which does not reflect the diversity of skills and interests of a diverse society. The discrepancy between the two assessment methods shows that the requirements for endogenous growth have not been met and that development prospects are limited $[61,62]$. The growth-oriented result can be justified by a very strong economic performance (Statistik Austria 2017a). At the same time also, the weak resilience-oriented result can be explained by the one-sided dependence on (winter) tourism, which is vulnerable to potential crises, especially considering the possible consequences of climate change [63].

In some instances, the two assessments also have consistent negative results, such as economic weakness and lack of resilience. The structurally weak alpine locations in Styria, East Tyrol, and Carinthia were in an obvious economic downward spiral over the entire period under study. These regions feature both natural challenges as well as a lack of motor units of the economy, so that they could not interrupt the cumulative decline. The natural environment made it difficult to fulfil the principles of resilience. Access to the labour market, short distances, mixed uses, and opportunities for education and training were only partially available or just to a limited extent.

Distinct differences between the results on the other hand could be observed in the north of Lower Austria (Waldviertel and Weinviertel). These regions demonstrated that resilience is possible without growth over almost the entire analyzed period. The economic and growth-oriented weakness can be explained by statistics on regional revenue. According to these statistics, the regions generate only average (Waldviertel) and low economic output (Weinviertel) compared to the national figures [64]. The results of the resilience-oriented assessment, that started out good and became worse at the end of the analyzed period, cannot be explained clearly. The good resilience-oriented result coincides with the fact that regional income inequalities in these areas are among the lowest in Austria [65]. Regional income inequalities represent a base for economic stability, social strength, exposure, and redundancy through equal employment [51,66,67]. The change in the resilience-oriented outcome may have had different causes. It could indicate a change in commuter dependencies, and thus, lower shares of internal commuters in the workforce. However, it could also have been caused by psychological mechanisms, such as self-fulfilling negative prophecies related to growth-oriented structural weakness, by means of which the original negative thinking influences actions and, in turn, leads to predicted changes $[68,69]$. An in-depth regional study could provide a more detailed explanation in this case.

The development trends in Vienna are noteworthy. The results for the capital city vary depending on the respective assessment, but the outcomes also vary within the assessment approaches. According to the growth-oriented assessment, the city was structurally strong in 1981 and 1991, otherwise slightly structurally weak or not clearly classifiable. According to the resilience-oriented assessment, the range of results is even wider. At the beginning of the analyzed period, resilience was not attributable, but in 2001 the results revealed the lack of resilience clearly. At the end of the analyzed period, Vienna, like the other centres, achieved a clear resilient structural strength but, according to the growth-oriented perspective, the negative and positive indicator values balance out, so no clear tendency can be identified. The evaluations of the individual indicators also differ from one point in time to another. As a consequence of the agglomeration's size and its concentration of economic and demographic development processes, the advantages and disadvantages a metropolis entails overlap, which in turn leads to a levelling out of positive and negative indicator values in the model, based on the utility analysis. Compared to the capitals of the other provinces, the spread of positive and also negative impacts on the surrounding countryside is quite limited, both in the growth-oriented as well as the resilience-oriented assessment.

These findings show that new insights into spatial development and regional resilience can also be gained on the basis of existing statistical data. The selection of the indicators and their evaluation, taking spatial statistics into consideration, provides the basis for interpretation. The hot-spot analysis proves very useful in this regional development study. The spatial distribution of development patterns 
and of resilience is clearly verifiable and can be explained using existing literature, in general terms for the time being. However, the scale of the investigation only allows for very generalized results on how structural strength and weakness is distributed in Austria. The results do not explain the exact causes of this distribution. Further research is needed to answer this question. Regions can be selected based on the results of this study, they need to be examined more closely, and the above-mentioned as well as other impact factors need to be analyzed. All of this forms the basis for elaborating a tailor-made recommended course of action.

\section{Conclusions and Outlook}

The study was conducted to gain deeper insights into regional development as well as into the emergence and development of spatial disparities. Two assessment approaches were applied to evaluate regional development, one based on the objective of increasing resilience and the other one on the objective of growth. Based on the assessments, the spatial development processes were interpreted based on the Austrian example. This led to an overview of the development processes, evaluated according to the two objectives. The instrument of resilience-oriented assessment clears the way for a new level of insight. Existing data is newly arranged and evaluated which enables conclusions on the ability of regions to handle crises. Clusters of high and low indicator values become apparent by means of spatial analysis. These kinds of results make it possible to determine the level of resilience of a region or an observation unit. There is no absolute scale for measuring resilience. It can only be evaluated relatively, comparing the resilience of different spatial units within the study area. The following striking similarities and differences between the development trends show: (1) Growth-oriented structural strength is related to resilience-oriented structural strength (e.g., Upper Austria and Salzburg); (2) growth-oriented structural weakness is related to resilience-oriented structural weakness (e.g., inner Alpine locations); (3) growth-oriented structural strength is related to resilience-oriented structural weakness (e.g., western Tyrol and eastern Vorarlberg); and (4) growth-oriented structural weakness is related to resilience-oriented structural strength (northern Lower Austria).

With this paper, an alternative approach to growth-oriented regional development analyses is presented, which may spur policy advice directed at sustainable development, while also taking limits of growth into account. We hope that this work inspires further researchers to engage in developing more methods to deliver spatial analyses beyond simple growth-thinking so that the knowledge base for sustainable development can be widened.

Author Contributions: Conceptualization, K.H. and G.S.; methodology, K.H. and G.S.; software, K.H.; validation, K.H.; formal analysis, K.H.; investigation, K.H.; data curation, K.H.; writing-original draft preparation, K.H.; writing-review and editing, G.S.; visualization, K.H.; supervision, G.S.; project administration, K.H.

Funding: This research received no external funding.

Conflicts of Interest: The authors declare no conflict of interest.

\section{References}

1. European Commission. The EU Regional Competitiveness Index 2016; Working Papers 02/2017; European Union: Brussels, Belgium, 2017; ISBN 978-92-79-65839-6.

2. ÖROK. Aufrechterhaltung der Funktionsfähigkeit Ländlicher Räume: Dienstleistungen der Daseinsvorsorge und Regionale Governance: Veränderungen, Herausforderungen, Handlungsbedarf; Schriftenreihe Nr. 171./Österreichische Raumordnungskonferenz; ÖROK: Wien, Austria, 2006; ISBN 978-3-85186-085-6.

3. Hndbuch Gemeindepolitik; Stainer-Hämmerle, K.; Oppitz, F. (Eds.) Verlag Österreich: Wien, Austria, 2013; ISBN 978-3-7046-6317-7.

4. WEF. The Global Competitioness Report 2017-2018; Klaus Schwab; World Economic Forum: Geneva, Switzerland, 2017.

5. Meadows, D.H.; Meadows, D.L.; Randers, J.; Behrens, W.W. The Limits to Growth: A Report for the Club of Rome's Project on the Predicament of Mankind; Universe Books: New York, NY, USA, 1972; ISBN 978-0-87663-165-2. 
6. United Nations. Johannesburg Declaration on Sustainable Development-A/CONF.199/20 Chapter 1, Resolution 1-UN Documents: Gathering a Body of Global Agreements; United Nations: Johannesburg, South Africa, 2002.

7. United Nations. Rio Declaration on Environment and Development-A/CONF.151/26 (Volume I) Chapter I, Annex I-UN Documents: Gathering a Body of Global Agreements; Rio de Janeiro, Brazil, 1992.

8. Holling, C.S. Resilience and Stability of Ecological Systems. Annu. Rev. Ecol. Syst. 1973, 4, 1-23. [CrossRef]

9. Erker, S.; Stangl, R.; Stoeglehner, G. Resilience in the light of energy crises-Part I: A framework to conceptualise regional energy resilience. J. Clean. Prod. 2017, 164, 420-433. [CrossRef]

10. Norris, F.H.; Stevens, S.P.; Pfefferbaum, B.; Wyche, K.F.; Pfefferbaum, R.L. Community Resilience as a Metaphor, Theory, Set of Capacities, and Strategy for Disaster Readiness. Am. J. Community Psychol. 2008, 41, 127-150. [CrossRef] [PubMed]

11. Walker, B.; Holling, C.S.; Carpenter, S.R.; Kinzig, A.P. Resilience, Adaptability and Transformability in Social-ecological Systems. Ecol. Soc. 2004, 9, 5. [CrossRef]

12. How's Life in Your Region? Measuring Regional and Local Well-Being for Policy Making; OECD (Ed.) OECD Publishing: Paris, France, 2014; ISBN 978-92-64-21741-6.

13. EU. Territoriale Agenda der Europäischen Union 2020_Für ein Integratives, Intelligentes und Nachhaltiges Europa der Vielfältigen Regionen; Treffen der für Raumordnung und Territoriale Entwicklung Zuständigen Ministerinnen und Minister: Gödöllő, Ungarn, 2011.

14. Österreichisches Raumentwicklungskonzept: ÖREK 2011; [Handlungsräume 2020; Österreichische Raumordnungskonferenz Beschluss vom 4. August 2011 (Schriftliches Verfahren)]; ÖROK (Ed.) Schriftenreihe/Österreichische Raumordnungskonferenz; Geschäftsstelle der ÖROK: Wien, Austria, 2011; ISBN 978-3-85186-100-6.

15. UN General Assembly Transforming Our World: The 2030 Agenda for Sustainable Development, A/RES/70/1. Available online: https://sustainabledevelopment.un.org/content/documents/21252030\% 20Agenda\%20for\%20Sustainable\%20Development\%20web.pdf (accessed on 23 November 2017).

16. Townsend, P. Deprivation. J. Soc. Policy 1987, 16, 125-146. [CrossRef]

17. Welsh Government. Welsh Index of Multiple Deprivation (WIMD) 2014; Llywodraeth Cymru Welsh Government: Cardiff, UK, 2014; ISBN 978-1-4734-2623-8.

18. DCLG. The English Indices of Deprivation (IMD) 2015-Guidance; Department for Communities and Local Government: London, UK, 2015.

19. NISRA. The Northern Ireland Multiple Deprivation Measures 2017; Northern Ireland Statistics and Research agency: Belfast, UK, 2017.

20. Scottisch Government Scottish Index of Multiple Deprivation. Available online: http://www.gov.scot/ Topics/Statistics/SIMD (accessed on 24 November 2017).

21. DCLG. The English Indices of Deprivation 2015: Technical Report; Department for Communities and Local Government: London, UK, 2015; ISBN 978-1-4098-4689-5.

22. Heintel, M.; Speringer, M.; Schnelzer, J.; Bauer, R. Regionale Benachteiligung und Daseinsgrundvorsorge am Beispiel des Oberpinzgaus: Ein Widerspruch? SIR-Mitteilungen Und Berichte 2016, 36, 99-108.

23. Maretzke, S. Regionale Disparitäten-eine bleibende Herausforderung. Informationen zur Raumentwicklung 2006, 9, 473-484.

24. Höferl, K.-M.; Jelinek, B. Vom Konstrukt zur Empirie: Beobachtungen zur „Strukturstärke bzw. Strukturschwäche“ österreichischer Gemeinden. In REAL CORP 007: To Plan Is Not Enough: Strategies, Plans, Concepts, Projects and Their Successful Implementation in Urban, Regional and Real Estate Development; CORP-Competence Center of Urban and Regional Development: Schwechat-Rannersdorf, Austria, 2007; pp. 781-790.

25. Chilla, T.; Kühne, O.; Neufeld, M. Regionalentwicklung; utb; Verlag Eugen Ulmer: Stuttgart, Germany, 2016; ISBN 978-3-8252-4566-5.

26. Handwörterbuch der Raumordnung; ARL (Ed.) Akad. für Raumforschung und Landesplanung: Hannover, Germany, 2005; ISBN 978-3-88838-555-1.

27. Neri, A.R. The importance of indices of multiple deprivation for spatial planning and community regeneration. The example of the welsh index of multiple deprivation and the related communities first programme for the Italian system. Ital. J. Plan. Pract. 2012, 2, 36-45. 
28. UNDP. Human Development Index (HDI) I Human Development Reports. United Nations Development Programme. Available online: http:/ /hdr.undp.org/en/content/human-development-index-hdi (accessed on 7 June 2018).

29. World Bank World Development Indicators. Available online: https://datacatalog.worldbank.org/dataset/ world-development-indicators (accessed on 1 June 2018).

30. Exner, A. Von der Nachhaltigkeit zur Resilienz? Mögliche Diskursveränderung in der Vielfachkrise | Social Innovation Network. Phase 2-Zeitschrift gegen die Realität 2013, Nr. 45-Ideologisch abbaubar. Available online: https://phase-zwei.org/hefte/artikel/von-der-nachhaltigkeit-zur-resilienz-408/ (accessed on 1 June 2018).

31. Wilson, G.A. Community Resilience and Environmental Transitions; Routledge: Abingdon-on-Thames, UK, 2012; ISBN 978-0-203-14491-6.

32. Bathelt, H.; Glückler, J. Wirtschaftsgeographie: Ökonomische Beziehungen in Räumlicher Perspektive; UTB Geowissenschaften, Soziologie, Wirtschaftswissenschaften, Politikwissenschaften; Ulmer: Stuttgart, Germany, 2012; ISBN 978-3-8252-8492-3.

33. Liefner, I.; Schätzl, L. Theorien der Wirtschaftsgeographie; UTB Wirtschaftswissenschaften, Geographie; Schöningh: Paderborn, Germany, 2012; ISBN 978-3-8252-3643-4.

34. Braun, B.; Schulz, C. Wirtschaftsgeographie; UTB UTB Basics; Verlag Eugen Ulmer: Stuttgart, Germany, 2012; ISBN 978-3-8252-3641-0.

35. Hirschmann, A.O. The Strategy of Economic Development. Ann. Am. Acad. Political Soc. Sci. 1959, 325, 125-126.

36. Myrdal, G. Economic Theory and Underdeveloped Regions; Duckworth: London, UK, 1957.

37. Prebisch, R. Commercial Policy in the Underdeveloped Countries. Am. Econ. Rev. 1959, 49, 251-273.

38. Bristow, G.; Healy, A.; Norris, L. ECR2—Economic Crisis: Resilience of Regions I ESPON; Final Report; European Union: Brussels, Belgium, 2014.

39. Wink, R.; Kirchner, L.; Koch, F.; Speda, D. Wirtschaftliche Resilienz in Deutschsprachigen Regionen; Springer: Wiesbaden, Germany, 2016; ISBN 978-3-658-09822-3.

40. Partzsch, D. Daseinsgrundfunktionen. In Handwörterbuch der Raumforschung und Raumordnung; Verlag der Akademie für Raumforschung und Landesplanung: Hannover, Germany, 1970; pp. 424-430.

41. Erker, S. Räumliche Resilienz im Hinblick auf Energiekrisen. In Regenerative Räume. Leitbilder und Praktiken nachhaltiger Raumentwicklung; ÖKOM-Verlag: Hamburg, Germany; Vaduz, Liechtenstein; Wien, Austria, 2017; ISBN 978-3-86581-834-8.

42. Stoeglehner, G.; Neugebauer, G.; Erker, S.; Narodoslawsky, M. Integrated Spatial and Energy Planning-Supporting Climte Protection and the Energy Turn with Means of Spatial Planning; SpringerBriefs in Applied Sciences and Technology; Springer International Publishing: Cham, Switzerland, 2016; ISBN 978-3-319-31868-4.

43. Woolcock, M. Social capital and economic development: Toward a theoretical synthesis and policy framework. Theory Soc. 1998, 27, 151-249. [CrossRef]

44. Wisner, B.; Gaillard, J.; Kelman, I. Framing Disaster: Theories and stories seeking to understand hazards, vulnerability and risk. In Handbook of Hazards and Disaster Risk Reduction; Routledge: Abingdon-on-Thames, UK, 2012; ISBN 978-0-203-84423-6.

45. Land Steiermark. Fact Sheet zum Thema "Freiwilligenarbeit in der Steiermark"; Amt der Steiermärkischen Landesregierung A6 Fachabteilung Gesellschaft und Diversität Referat Frauen, Gleichstellung und Integration: Graz, Austria, 2015.

46. Putnam, R.D. What makes democracy work? Natl. Civ. Rev. 1993, 82, 101-107. [CrossRef]

47. Exner, A.; Politti, E.; Schriefl, E.; Erker, S.; Stangl, R.; Baud, S.; Warmuth, H.; Matzenberger, J.; Kranzl, L.; Paulesich, R.; et al. Measuring regional resilience towards fossil fuel supply constraints. Adaptability and vulnerability in socio-ecological Transformations-the case of Austria. Energy Policy 2016, 91, 128-137. [CrossRef]

48. Hage, G.; Jacoby, C.; Kotzold, K.; Reichert, F. Interreg IIIA-Projekt DACH+ Raumentwicklung im Grenzraum Deutschland-Österreich-Schweiz-Lichtenstein. Raumentwicklung und Raumbeobachtung im DACH+ Grenzraum. Werkstattbericht; Tübingen: Brunnthal und Rottenburg, Germany, 2008. 
49. Kröhnert, S.; Klingholz, R. Not am Mann: Von Helden der Arbeit zur Neuen Unterschicht? Lebenslagen Junger Erwachsener in Wirtschaftlichen Abstiegsregionen der Neuen Bundesländer; Berlin-Institut für Bevölkerung und Entwicklung, Ed.; 1. Aufl.; Berlin-Institut für Bevölkerung und Entwicklung: Berlin, Germany, 2007; ISBN 978-3-00-021678-7.

50. Weber, G.; Fischer, T. Gehen oder Bleiben? Die Motive des Wanderungs- und Bleibeverhaltens junger Frauen im ländlichen Raum der Steiermark und die daraus resultierenden Handlungsoptionen; Online-Fachz. Des Bundesminist. Für Land- Und Forstwirtsch; Umw. Und Wasserwirtschaft: Wien, Austria, 2012.

51. Wilkinson, R.G.; Pickett, K. The Spirit Level: Why More Equal Societies Almost Always Do Better; Allen Lane: London, UK, 2009; ISBN 978-1-84614-039-6.

52. Kawka, R. Gleichwertigkeit messen. Informationen zur Raumentwicklung 2015, 1, 71-80.

53. Getis, A.; Ord, J.K. The Analysis of Spatial Association by Use of Distance Statistics. Geogr. Anal. 1992, 24, 189-206. [CrossRef]

54. ESRI. Funktionsweise der Hot-Spot-Analyse (Getis-Ord Gi*)—HilfelArcGIS Desktop. Available online: http://desktop.arcgis.com/de/arcmap/10.5/tools/spatial-statistics-toolbox/h-how-hot-spotanalysis-getis-ord-gi-spatial-stati.htm (accessed on 15 April 2018).

55. ESRI. Funktionsweise der Optimierten Hot-Spot-Analyse-HilfelArcGIS Desktop. Available online: http:/ / desktop.arcgis.com/de/arcmap/10.5/tools/spatial-statistics-toolbox/how-optimized-hotspot-analysis-works.htm (accessed on 15 April 2018).

56. Dax, T.; Fidlschuster, L.; Ficher, M.; Hiess, H.; Oedl-Wieser, T.; Pfefferkorn, W. Regionen mit Bevölkerungsrückgang Experten-Impulspapier zu regional- und raumordnungspolitischen Entwicklungs- und Anpassungsstrategien; Im Auftrag des Bundeskanzleramts Österreich: Wien, Austria, 2016.

57. ÖROK. ÖROK-Atlas. Available online: https:/ / www.oerok-atlas.at/ (accessed on 4 June 2018).

58. Friedmann, J.R.P. Regional Development Policy: A Case Study of Venezuela; MIT Press: Cambridge, MA, USA; London, UK, 1966; ISBN 978-0-262-06013-4.

59. World Bank World Bank Open Data. Available online: https:/ / data.worldbank.org (accessed on 3 August 2018).

60. Land Tirol Tourismus in Tirol. Available online: https://www.tirol.gv.at/statistik-budget/statistik/ tourismus / (accessed on 5 June 2018).

61. Romer, P.M. Endogenous Technological Change. J. Political Econ. 1990, 98, 71-102. [CrossRef]

62. Tödtling, F. Endogenous approaches to local and regional development policy. In Handbook of Local and Regional Development; Routledge: Abingdon-on-Thames, UK, 2014; ISBN 978-0-203-84239-3.

63. Pröbstl, U. Klimawandel: Zukunft und Herausforderung für den Tourismus; Ländlicher Raum. Online-Fachzeitschrift des Bundesministeriums für Land- und Forstwirtschaft, Umwelt und Wasserwirtschaft: Wien, Austria, 2007; p. 13.

64. Statistik Austria Regionale Gesamtrechnungen. Bruttowertschöpfung zu Herstellungspreisen nach NUTS 3-Regionen. Available online: https://www.statistik.at/web_de/statistiken/wirtschaft/ volkswirtschaftliche_gesamtrechnungen/regionale_gesamtrechnungen/nuts3-regionales_bip_und_ hauptaggregate/019477.html (accessed on 5 June 2018).

65. Statistik Austria Registerbasierte Statistiken Einkommen (RS) Kalenderjahr 2013. Auswertungen der Lohnsteuerstatistik 2004-2010. Available online: http:/ / www.statistik.at/web_de/statistiken/menschen_ und_gesellschaft/soziales/personen-einkommen/index.html (accessed on 5 June 2018).

66. Galbraith, J.K. Inequality and Instability: A Study of the World Economy Just before the Great Crisis, 1st ed.; Oxford University Press: New York, NY, USA, 2012; ISBN 978-0-19-985565-0.

67. Stiglitz, J.E.; Schmidt, T. Der Preis der Ungleichheit: Wie die Spaltung der Gesellschaft Unsere Zukunft Bedroht; Siedler: München, Germany, 2012; ISBN 978-3-8275-0019-9.

68. Merton, R.K. The Self-Fulfilling Prophecy. Antioch Rev. 1948, 8, 193. [CrossRef]

69. Rosenthal, R.; Jacobson, L. Pygmalion in the classroom. Urban Rev. 1968, 3, 16-20. [CrossRef]

(C) 2019 by the authors. Licensee MDPI, Basel, Switzerland. This article is an open access article distributed under the terms and conditions of the Creative Commons Attribution (CC BY) license (http://creativecommons.org/licenses/by/4.0/). 